\title{
The Belt and Road Policy and Traditional Chinese Culture
}

\author{
Wei Zheng ${ }^{1} \&$ Qing-Xiang Feng ${ }^{2}$ \\ ${ }^{1}$ School of Marxism Studies, Central University of Finance and Economics, Beijing, China \\ ${ }^{2}$ Institute of Guangdong Hong Kong and Macao Development Studies, Sun Yat-sen University, Guangzhou, \\ China \\ Correspondence: Qing-Xiang Feng, Institute of Guangdong Hong Kong and Macao Development Studies, Sun \\ Yat-sen University, Guangzhou 510275, China. E-mail: fengqx8@mail.sysu.edu.cn
}

Received: August 10, 2019

Accepted: August 30, 2019

Online Published: August 31, 2019

doi:10.5539/ach.v11n2p87

URL: https://doi.org/10.5539/ach.v11n2p87

\begin{abstract}
Since the 18th CPC national congress, the development of socialism with Chinese characteristics has entered into a new era. In the new context of development, Chinese President Xi Jinping has put forward the Belt and Road Policy. The Belt and Road Policy is not only a major decision for China to promote regional economic integration and international economic and trade exchanges, but also a project to spread traditional Chinese culture. The Belt and Road Policy initiative bears the mission of spreading the Chinese civilization and building a community with a shared future for humanity. It attempts to provide a set of Chinese solutions to the bottleneck of global development and demonstrates the cultural confidence of the CPC.
\end{abstract}

Keywords: China, The Belt and Road Policy, Traditional Chinese Culture

\section{Introduction}

Chinese President -Xi Jinping said in the 19th CPC national congress that socialism with Chinese characteristics has entered into a new era, marking a new historical juncture in China's development. In the report, he also mentioned that the Belt and Road (B\&R) Policy -construction has achieved remarkable results. The B\&R is not only a strategy for international and regional economic development, but also a "golden key" for strengthening all-round cooperation among countries around the world. Among them, the dissemination of traditional Chinese culture is an indispensable part. Under the background of China's new era, it is of great significance to understand the construction of $\mathrm{B} \& \mathrm{R}$ and the spread of traditional Chinese culture in order to deeply understand Chinese civilization and China's national strategic layout.

In his speech at Nazarbayev University in Kazakhstan on September 7, 2013, President Xi Jinping put forward the initiative of jointly building the "Tilk Road Economic Belt" with innovative cooperation models. In a speech to the Indonesian parliament on October 3 , he put forward the idea of jointly building the $21^{\text {st }}$-Century Maritime Silk Road with southeast Asian countries. This marks the beginning of China's B\&R initiative. On March 27, 2015, the national development and reform commission, the ministry of foreign affairs and the ministry of commerce in Bo-ao Asia on jointly issued the "vision and actions of jointly building the Silk Road Economic Belt and the

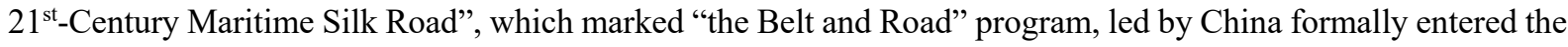
stage of comprehensive construction, also marks the Chinese positive impetus region to participate in the change of the role of globalization and international economic new order.

In May 2017, B\&R International Cooperation Summit was held in Beijing. This is the highest-level and largest international conference within the framework of $B \& R$ initiated by China. In his keynote speech, President Xi Jinping pointed out that since the launch of the B\&R in 2013, it has gradually been transformed from an idea into an action, from a vision into a reality, and yielded fruitful results. First, policy communication has been deepened. Second, infrastructure connectivity has been strengthened. Third, unimpeded trade continued to improve. Fourth, financial connectivity continued to expand. Fifth, increasing people-to-people connectivity. At the meeting, all parties agreed to build B\&R into a road to peace, prosperity, openness, innovation and civilization. In April 2019, Xi Jinping pointed out in the opening speech of the second B\&R International Cooperation Summit Roundtable that the goal of jointly building B\&R international cooperation is to create more benefits for people of all countries and make greater contribution to building a community of Shared future for mankind. 
In order to cooperate with $B \& R$ construction planning, as early as 2016 , the $B \& R$ cultural development action plan (2016-2020) formulated by the ministry of culture of China makes specific arrangements from the aspects of $B \& R$ cultural exchange mechanism construction, cooperation platform, brand building, cultural industry development and trade cooperation. Among them, especially for the internationalization of traditional Chinese culture spread made a specific arrangement.

Since the B\&R was put forward, its planning has been more focused on infrastructure construction and economic development, but it also contains the communication, development and common prosperity of different cultures. This reflects the value and significance of traditional Chinese culture in the interaction between China and the world today.

\section{View}

The B\&R put forward by Chinese President Xi Jinping embodies the wisdom and essence of traditional Chinese culture, such as the concept of valuing justice over interests, peace and cooperation, and innovation and opening up.

\section{1 "The Belt and Road" Reflects the Concept of Valuing Justice over Profits in Traditional Chinese Culture}

In the long process of natural economic development in ancient China, the traditional cultural thought with Confucian ethics as the core was formed. This traditional Chinese cultural thought is reflected in the economic life and People's Daily communication. It mainly focuses on the relationship between righteousness and interests. It takes "seeing benefit and thinking about justice" as the core, "benevolence", "justice", "sincerity" and "faith" as the fundamental, and advocates putting benevolence, justice and morality before interests, and social collective interests before personal interests.

The traditional concept of righteousness and interests is always carried out in the history of Traditional Chinese culture and ideology, which is regarded as one of the important issues in Chinese ethical relations. For example, $\mathrm{Zhu} \mathrm{Xi}$, a master of Neo-Ceonfucianism in the Ming dynasty, believed that "the doctrine of righteousness and profit is the first principle of Confucianism". In the debate of justice and interests, there are mainly such viewpoints as "justice is valued and interests are neglected", "justice and interests are unified", "justice and interests are considered" and so on, putting the concept of "justice" in an extremely important position. The Belt and Road not only borrows the concept of silk economic and cultural exchanges gradually formed in the Han and Tang dynasties, but also reflects that China takes care of the vital interests of neighboring countries and regions in the development process. In a nutshell, China places its economic thinking about national development in the context of the developing world as a whole, as well as in the context of historical and global developments.

The highest value goal of the concept of righteousness and interests of traditional Chinese culture is to pursue social harmony, which is highly consistent with the collectivism insisted by socialism with Chinese characteristics. Collectivism is an important gene of the socialist economy with Chinese characteristics. It not only focuses on the economic development of a particular person or region, but also comprehensively considers the economic development of the whole society, the whole country, or even a region or the whole world. From the perspective of traditional Chinese culture and economic theory, B\&R runs through the value appeal of collectivism and is committed to improving the overall well-being of different regions and local residents in the world.

\section{2 "The Belt and Road" Embodies the Concept of Peace and Cooperation in Traditional Chinese Culture}

Since the 18th national congress of the communist party of China, President Xi Jinping, taking into account the new situation in traditional Chinese culture and international politics and economy, has put forward a new approach of unswervingly pursuing peaceful development and win-win cooperation. Among them, President Xi Jinping stressed that peace-loving is a tradition of Chinese culture and the Chinese nation is peace-loving. To uphold peaceful development is an important historical experience of the $\mathrm{CPC}$ in its revolutionary exploration and social practice. The zero-sum mentality can no longer meet the current needs. To achieve prosperity and development, the country needs to adhere to peace, development, cooperation and win-win situation in light of the current trend of world development. This is the modern value of the concept of "harmony" in traditional Chinese culture. China upholds the principles of amity, sincerity, mutual benefit and inclusiveness, and advocates that China's diplomatic activities with neighboring countries should follow the principles of good-neighborliness, security and prosperity, and fully respect the sovereignty of neighboring countries. The Silk-Road embodies the spirit of peace, cooperation, mutual benefit and mutual benefit in traditional Chinese culture. The B\&R was put forward under the guidance of this series of international cooperation and exchange ideas. It implements the spirit of traditional Chinese culture, emphasizes the establishment of harmonious, cooperative and peaceful relations 
between the whole and the individual, realizes the common development and prosperity of all countries and regions in the world, and opposes hegemonism.

Innovative and open attitude is an important quality of traditional Chinese culture. On traditional Chinese culture, President Xi Jinping has put forward the concept of "creative transformation" and "innovative development". The first is about the transformation and development of traditional Chinese culture itself. Second, on this basis, we should face the future and expand the new connotation of Chinese culture. The Chinese nation is an important member of the world nation. The development of Chinese national culture cannot be separated from the development of world civilization. Likewise, the development of world civilization cannot be separated from the development of Chinese national culture. Therefore, traditional Chinese culture should not only go to the future, but also face the world.

President Xi Jinping has proposed that to create a new splendid Chinese culture in the future, there are four ways: first, we should base ourselves on the basis of the excellent traditional Chinese culture. Second, it should be guided by the theoretical achievements of sinicization of Marxism, which not only contains the Chinese revolutionary tradition left by the early Chinese communists, but also contains the accurate understanding of the essence of socialism since the reform and opening up. Third, it should be closely combined with era calls, take care of the current historical reality, and reflect the spirit of era; Fourth, we need to keep an open and inclusive attitude and draw on the beneficial achievements of world civilizations.

Similarly, the B\&R should be oriented to the world and the future, which cannot be separated from open exchanges with different civilizations in the world. Civilizations are colorful, equal and open. Countries should enhance exchanges and mutual learning to jointly promote the progress of human civilization and world peace and development. To promote inter-civilization exchanges and mutual learning, we need to uphold the right attitude and principles. Different ethnic groups have their own track of development and evolution, and civilizations are diverse. The Chinese civilization and other civilizations have their own merits, just like a hundred flowers blooming in full bloom. At the same time, there is no distinction between high and low civilizations. Civilizations are equal in status and should treat each other with respect and tolerance. The Belt and Road stressed that the traditional Chinese culture in the collisions with the world civilization and the process of communication, not only to the dialectical reference, and insist on confidence, our culture bravely "going out", learn to learn from all the good civilization achievement of human society, seek wisdom from a different civilization, to build with Chinese characteristics, Chinese style, Chinese style culture brand, to show the unique charm of the Chinese culture.

\section{Conclusions}

The fine traditional Chinese culture is extensive and profound and has a long history. Through thousands of years of accumulation, it has gradually compiled the cultural genetic code of the Chinese nation, which is engraved on the identity of Chinese people. It has always shaped, nurtured and nourished the way of thinking, value orientation, cultural habits and behavior of the Chinese people. Since modern times, under the impact of western culture with religion and reason as the main symbols, Confucianism, Buddhism, Taoism, Law and other traditional Chinese cultural forms have gone through many twists and turns, constantly breaking through their own limitations, and responding to the development requirements of era calls, they have undergone creative transformation and innovative development, and the concentrated essence of thought has always been shining.

In the process of economic, trade and cultural exchanges with the world, the B\&R Policy proposed by China will become an important window to show the elegant style of traditional Chinese culture and socialist economy and culture with Chinese characteristics. It also will provide new opportunities for China and international exchanges on "harmony" and "cooperation". We should realize that the Belt and Road Policy embodies the wisdom of traditional Chinese culture, embodies the value of traditional Chinese culture in the development of world civilization, and shows the unique content of Chinese temperament, image and spirit in the new era.

\section{Conflict of interests}

The authors declare that there is no conflict of interests regarding the publication of this paper.

\section{References}

Bao, X. J. (2004). Historical Experience and Basic Rules of Sinicization of Marxism. Shandong Social Sciences, 7, 9-17.

Central Literature Research Office. (2014). Xi Jinping on Governance. Foreign Languages Press, 287-295.

Chen, X. D. (2015). Marxism and Traditional Chinese Culture. People's Publishing House, 1-30. 
Li, W. Y., \& Liu, H. D. (2016). Construction of the Belt and Road from Multi-dimensional Distance Perspective. Exploration of International Economy and Trade, 32(06), 99-112.

Propaganda Department of the CPC Central Committee. (2016). Xi Jinping's Series of Important Speeches. Learning Press and People's Publishing House, 266-268.

Xi, J. P. (2017). Jointly Promote the Construction of the Belt and Road. People's Daily.

\section{Copyrights}

Copyright for this article is retained by the author(s), with first publication rights granted to the journal.

This is an open-access article distributed under the terms and conditions of the Creative Commons Attribution license (http://creativecommons.org/licenses/by/4.0/). 